\title{
Fluvial flux of nitrogen from Great Britain 1974-2005 in the context of the terrestrial nitrogen budget of Great Britain
}

\author{
F. Worrall, ${ }^{1}$ T. P. Burt, ${ }^{2}$ N. J. K. Howden, ${ }^{3}$ and M. J. Whelan ${ }^{3}$ \\ Received 27 August 2008; revised 21 May 2009; accepted 28 May 2009; published 18 September 2009.
}

[1] Long-term records of the concentration of nitrogen species from British rivers were compiled in order to assess temporal change in the total fluvial nitrogen flux compared to the other inputs to, and outputs from, the UK terrestrial biosphere. The following nitrogen species are considered: ammoniacal $\mathrm{N}$, nitrate, nitrite, dissolved organic nitrogen, and particulate organic nitrogen. Concentration and flow records were reconstructed from 1974 to 2005 for ammoniacal N, nitrate, nitrate, and dissolved organic nitrogen (DON) and from 1992 for particulate organic nitrogen (PON). The reconstructed fluvial nitrogen time series was compared to records for inorganic fertilizer, atmospheric emissions, industrial and sewage effluent, and imports. The results show that (1) the total dissolved nitrogen flux over the study period, after flow correction, varied from 470 to $980 \mathrm{kt} \mathrm{N}$ $\mathrm{a}^{-1}$, which, on average, comprised $69 \%$ nitrate $\mathrm{N} ; 26 \%$ dissolved organic $\mathrm{N} ; 4 \%$ ammoniacal $\mathrm{N}$; and $1 \%$ nitrite $\mathrm{N}$; (2) the total nitrogen flux including PON varied from 504 to $1004 \mathrm{kt} \mathrm{N} \mathrm{a}^{-1}$; (3) the flux of ammoniacal $\mathrm{N}$ shows a significant decline over the study period, but significant increases in both nitrate $\mathrm{N}$ and dissolved organic $\mathrm{N}$ mean that the total dissolved nitrogen flux still shows a significant increase at a rate of $6.3 \mathrm{kt} \mathrm{N}$ $\mathrm{a}^{-1}$; and (4) the dissolved nitrogen flux record shows both a steady increase over the period 1974 to 2005 and sharp discrete rises in response to severe droughts. Flux increases (up to $69 \%$ increase compared to the 4 years prior to the drought) in response to severe droughts are not consistent with a storage effect caused by reduced flows but, instead, appear to represent enhanced production in the year of the drought. The long-term rise of fluvial nitrogen flux from British rivers is in contrast to declines in inputs and other $\mathrm{N}$ outputs.

Citation: Worrall, F., T. P. Burt, N. J. K. Howden, and M. J. Whelan (2009), Fluvial flux of nitrogen from Great Britain 1974-2005 in the context of the terrestrial nitrogen budget of Great Britain, Global Biogeochem. Cycles, 23, GB3017, doi:10.1029/2008GB003351.

\section{Introduction}

[2] Estimates suggest that human activity has doubled the rate at which biologically available nitrogen enters the terrestrial biosphere compared with preindustrial levels [Galloway et al., 2004]. Increased inputs of nitrogen to land have resulted in: a deterioration of drinking water quality and may have contributed to eutrophication in some receiving water bodies with consequent increased occurrence of algal blooms, reduced dissolved oxygen levels and loss of habitat [Turner and Rabalais, 1994; Vitousek et al., 1997]. It is, therefore, important to understand and quantify nitrogen exchanges to and from the terrestrial biosphere. A number of empirical approaches have been developed for predicting the influence of natural and anthropogenic

\footnotetext{
${ }^{1}$ Department of Geological Sciences, Science Laboratories, Durham University, Durham, UK.

${ }^{2}$ Department of Geography, Science Laboratories, Durham University, Durham, UK.

${ }^{3}$ Natural Resources Department, School of Applied Sciences, Cranfield University, Cranfield, UK.

Copyright 2009 by the American Geophysical Union. 0886-6236/09/2008GB003351\$12.00
}

changes on nitrogen transfers from land to water [e.g., Seitzinger et al., 2005]. However, most of these approaches have been calibrated using data for a limited number of years (commonly from the mid-1990s) from catchments where nitrogen fluxes could be increasing in response to changing anthropogenic influences.

[3] For the United Kingdom, the flux of nitrate and ammonia has been reported annually since 1990 as part of the UK Government's commitments under the Oslo and Paris Treaties [OSPAR Commission, 2007]. However, this reported flux has several limitations. First, the reported flux does not include all forms of nitrogen, most importantly dissolved organic nitrogen (DON) and particulate organic nitrogen (PON). Second, this is only reported from 1990, even though national-scale monitoring programs have existed for much longer (e.g., Harmonised Monitoring Scheme (HMS) since 1974 [Simpson, 1980]). Third, the results are not rescaled to cover the whole country. Other national-scale studies of nitrate do exist for the United Kingdom. Marsh [1980] was probably the first to attempt a nitrogen balance for the United Kingdom, albeit limited to nitrate. Betton et al. [1991] produced maps of both average nitrate concentration and nitrate export for Great Britain but 
did not calculate a total nitrate flux value for the whole country. Littlewood and Marsh [2005] have used nitrate concentration data from the HMS to develop fluvial flux methodologies. Davies and Neal [2007] have used the average nitrate concentration data from the HMS in order to predict the factors controlling average concentrations and connections with land use but did not consider fluxes. Nedwell et al. [2002] assessed the fluxes of ammonia and inorganic nitrogen to $20 \mathrm{UK}$ estuaries for 1995-96 but did not scale these estimates to the national level or include DON or PON. Hope et al. [1997], Worrall and Burt [2007], and Worrall et al. [2007a] have considered the UK national fluxes of dissolved organic carbon (DOC) and particulate organic carbon (POC) but did not report fluxes of DON or PON.

[4] Given the population density of the United Kingdom, the extent of high-input agriculture within the country and the small, relatively unimpeded nature of UK rivers, a hypothesis is that the United Kingdom represents a hot spot of nitrogen flux to the surrounding marine environment. This study addresses this hypothesis by (1) calculating the total fluvial nitrogen flux from the landmass of Great Britain including all dissolved and particulate forms, (2) calculating this flux over the longest possible time period in order to indentify and understand any trends, and (3) comparing the calculated flux to the other environmental exchanges of nitrogen for the United Kingdom.

\section{Methodology}

[5] This study considers the fluvial nitrogen flux from British rivers. Note that the study is focused on the island of Great Britain and excludes Northern Ireland. The following forms of nitrogen are included: total ammoniacal $\mathrm{N}$ (principally ammonium but including unionized ammonia), nitrate, nitrite, DON and PON. The data used for the flux calculations was obtained from the Harmonised Monitoring Scheme (HMS).

\subsection{Harmonized Monitoring Scheme}

[6] The HMS was established in 1974 to measure important hydrochemical fluxes to the North Atlantic and to allow their trends to be monitored [Simpson, 1980]. These measurements met the United Kingdom's commitment to a series of international agreements and treaties [Bellamy and Wilkinson, 2001]. There are 56 HMS sites in Scotland and 214 sites in England and Wales. Monitoring sites were placed at the tidal limits of all rivers with an average annual discharge of over $2 \mathrm{~m}^{3} \mathrm{~s}^{-1}$, with additional sites placed on major tributaries. These criteria mean that there is good spatial coverage of the coast of England and Wales, but in Scotland many of the west coast rivers are too small to warrant inclusion in the HMS. A range of water quality parameters are measured at these sites. Those pertinent to this study are nitrogen as nitrate, ammonium and nitrite. The HMS does not measure DON. In this study we assume that this can be derived from the flux of DOC, given a knowledge of the $\mathrm{C} / \mathrm{N}$ ratio typical of fluvial DOC. The flux of DOC can be derived from the HMS using the approach of Worrall and Burt [2007]. Particulate organic nitrogen (PON) is also not measured in the HMS but this study assumes that PON can be derived from the suspended sediment flux coupled with a knowledge of the organic carbon content and $\mathrm{C} / \mathrm{N}$ ratio typical of suspended sediment.

[7] Monitoring is the responsibility of regional offices of the Environment Agency in England and Wales and the Scottish Environment Protection Agency in Scotland. As a result, sampling frequencies vary ranging from subweekly to monthly (or even less frequently in some cases). Data from any year at any site where less than 12 samples were collected in that year were excluded from the analysis. Consequently, although there are 254 harmonized monitoring sites across Great Britain, the number of sites which were included in any one year was variable: the smallest being 85 sites in 2001 and the largest being 170 in 1981 . Note that although, the HMS network may include several sampling locations in any one catchment, only data from each of the most seaward site was considered here. The distribution of sites from which data were used is shown in Figure 1.

\subsection{Flux Calculation}

[8] A wide range of methods have been proposed for calculating river fluxes from concentration and flow data [e.g., De Vries and Klavers, 1994; Littlewood, 1995]. These methods differ between interpolation methods [e.g., Walling and Webb, 1985; Littlewood, 1995; Webb et al., 1997] and extrapolation methods [e.g., Duan, 1983]. Webb et al. [2000] generated synthetic concentration time series and tested a number of flux estimation methods and suggested that interpolation methods were generally more reliable and less prone to errors than the more complex extrapolation methods. Extrapolation methods usually work best where a good rating curve between concentration and flow has been established. However, this is not the case with determinands where there is a strong seasonal component, such as nitrate, nitrite, ammonium and DOC [Naden and McDonald, 1989]. For cases where data are relatively sparse, such as in much of the HMS, Littlewood et al. [1998] suggested that the product of flow weighted concentration and the annual discharge [Verhoff et al., 1980] was most appropriate. However, HMS sampling is generally aperiodic and the following method [Rodda and Jones, 1983] is more appropriate:

$$
\begin{gathered}
F_{j y}=K A_{y} \sum_{1}^{N} n_{y} C_{i} Q_{i} \\
n_{y}=\frac{A_{y}}{N_{y}} \\
F_{y G B}=\frac{\operatorname{Area}_{G B}}{\sum_{I}^{J} \operatorname{Area}_{j}} \sum_{i}^{j} F_{j y}
\end{gathered}
$$

where $F_{j y}$ is the annual flux at the site $\mathrm{j}$ for a given year $y\left(\mathrm{t} \mathrm{N} \mathrm{a}^{-1}\right) ; C_{i}$ is the measured concentration at the site at time $i\left(\mathrm{mg} \mathrm{N} \mathrm{L}^{-1}\right) ; Q_{i}$ is the river discharge at time $i\left(\mathrm{~m}^{3}\right.$ 


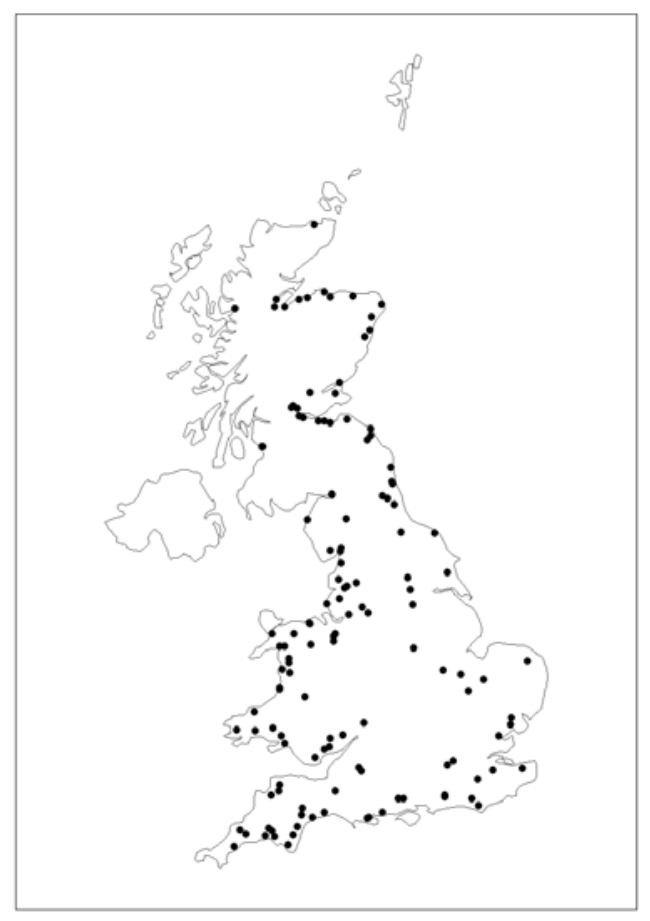

Figure 1. Location of the Harmonised Monitoring Scheme sampling sites used in this study.

$\left.\mathrm{s}^{-1}\right) ; K$ is a conversion factor which takes into account the units used (0.0864); $n_{y}$ is average number of days between samples (days); $N_{y}$ is the number of samples at the site in year $y ; A_{y}$ is the number of days in year $y$ (can vary with a leap year); $\mathrm{F}_{\mathrm{yGB}}$ is the flux from Great Britain in year $y(\mathrm{t} \mathrm{N})$; Area ${ }_{\mathrm{GB}}$ is the area of Great Britain $\left(\mathrm{km}^{2}\right)$; and Area $_{j}$ is area of the catchment to site $j$ $\left(\mathrm{km}^{2}\right)$. This approach assumes that each sample taken at a site is equally likely to be representative of an equal proportion of the year as any other sample. One component of the fluvial nitrogen flux that does not have a strong seasonal component is the suspended sediment concentration [Walling and Webb, 1982]. However, the HMS database does not allow for complex extrapolation methods based on rating curves to be used and so the interpolation method is used here as well.

[9] From the flux for each HMS site in each year for each determinand, the export rate is calculated as the flux per unit catchment area per year. The flux from Great Britain was then calculated using an area-weighted average of export rates (equation (3)). The total regional flux was then calculated from the area weighted average export and the regional area. The flux from all the regions was summed to give the national flux. This approach better represents regional hot spots without biasing the national value due to uneven spatial distribution of available records while at the same time using all site information in the calculation of national-scale flux. Even using this method, which takes advantage of all site information, there are still years where a region may have no sample sites. If for 1 year, data were missing for a particular region, then the average of the previous and subsequent years was used. If there were no sample sites for a region for more than 1 year, then linear regression was used to predict missing values by correlating available data between neighboring regions.

\subsection{Error Estimation}

[10] There are several sources of error within the calculation. First, low sampling frequency often leads to underestimation of fluxes as high concentrations tend to be undersampled [Walling and Webb, 1985; Littlewood and Marsh, 2005]. This is less of a problem for nitrate as concentrations vary little with flow relative to other determinands. In this study where sampling frequencies varied, some catchment flux estimates were based on as little as 12 samples per year, while other sites were calculated on the basis of as many 158 samples per year. In order to assess the error due to changing sampling frequency the analysis at the most frequently sampled site in the data set is considered. From the 158 paired concentration and discharge measurements at this site, the samples were divided into their individual months, and 200 sets of 12 data points were randomly sampled, one from each month. The annual flux was then calculated for each set. Second, the area-weighted method used to upscale the catchment fluxes to the region assumes that the available catchment data were representative of the region as a whole. In order to understand the error associated with upscaling the year with the most sampled catchments, 1981, was considered. In this year, a range of catchment exports was calculated for each region and the areaweighted average of the available export rate was compared with regional export estimates based on the 5th and 95th percentile export values (scaled up accordingly). This provides an upper and lower limit of the regional and, in turn, of the national flux.

[11] The calculation of the DON and PON fluxes requires use of literature estimates of the $\mathrm{C} / \mathrm{N}$ ratio of the dissolved and suspended matter and the organic carbon content of the suspended sediment. The suspended sediment concentration can vary in organic carbon content, and for British rivers, Hope et al. [1997] preferred a value of 14\%. Neal [2003] studied sediment from rivers with catchment areas from 373 to $8231 \mathrm{~km}^{2}$; organic carbon contents varied from 5 to $17 \%$. As the latter study is more comprehensive in terms of area and river type, this study will calculate POC flux considering a range of organic carbon content of suspended sediment of $5-17 \%$ with the median value of $11 \%$ being taken as the preferred value. Hillier [2001] studied suspended sediment throughout the River Don catchment in Scotland (area of $1320 \mathrm{~km}^{2}$ ); the average $\mathrm{C} / \mathrm{N}$ ratio was 8.1 with a range of $5.2(n=13)$.

\subsection{Additional Data}

[12] The annual fluvial fluxes calculated for Great Britain were flow corrected using the approach of Raymond et al. [2008], where the flux is multiplied by the ratio of the current year's total flow compared to the average total annual flow across the entire period 1974 to 2005 . In this way, flow correction of the flux of each component is normalized to the average annual total flow. Flow correction in this manner is used to ensure that changes observed are 
changes in release of nitrogen species and not just a change in water flux: both uncorrected and flow-corrected fluxes are presented. The total annual river runoff from Great Britain was derived from records maintained by the National Riverflow Archive (NRFA, http://www.ceh. ac.uk).

[13] The fluvial flux of nitrogen was compared to other terrestrial and atmospheric fluxes of nitrogen. This study follows the method of Smil [1999], as used by Boyer et al. [2002, 2006]. The inputs considered were: planted seeds and tubers; atmospheric deposition; irrigation water; recycling of crop residues; human and animal wastes; biological nitrogen fixation; synthetic inorganic fertilizers; and food and feed transfers. The outputs considered were: atmospheric emissions; leaching; soil erosion; and food and feed transfers. The fluvial flux of nitrogen, as conceived above, already incorporates a number of these including both leaching and soil erosion and sewage and waste discharges to rivers. However, there is also direct sewage output to the sea. The OSPAR Commission has reported fluxes of nitrate, ammonium and suspended particular matter (SPM) for industrial and sewage wastes since 1990 [OSPAR Commission, 2007]. The SPM data was converted to a PON flux as above. However, no data were reported for nitrite or for direct fluxes of DON. In the case of nitrite and DON it was assumed these were emitted in the direct marine inputs in the same proportions as they occurred in the fluvial flux at the tidal limit.

[14] Biological fixation can occur in all ecosystems and can represent a significant input of nitrogen. For agricultural systems the approach of Smil [1999] was used, although updates to this method have been published by Herridge et al. [2008] the updates are for crop and land types not found in the United Kingdom. The area of nitrogen fixing crops for the United Kingdom was considered to consist exclusively of legumes (predominantly beans and peas) and clover, as part of crop rotation. The area of each of these was available from 1986 onward as part of the UK agricultural annual census returns (Ministry of Agriculture Fisheries and Food (MAFF), Agriculture in United Kingdom, HMSO, London, 1975-2000; Department of Environment, Food and Rural Affairs (DEFRA), Agriculture in the United Kingdom, HMSO, London, 2001-2006). For both clover and legumes the middle estimate of $\mathrm{N}$ fixation as reported by Smil [1999] was used. For biological fixation in natural ecosystems, as opposed to agricultural systems, the approach of Cleveland et al. [1999] was used. For the United Kingdom it was assumed that the majority of natural ecosystems fall into the classes of temperate forest or temperate grassland as defined by Cleveland et al. [1999]. The area of UK forest was taken as that quantified in 1980 (Forestry Commission, quoted by Department of Environment, Food and Rural Affairs, E-digest of statistics, 2008, http://www.defra.gov.uk). The area of the United Kingdom that is not under forestry, or under clover or under peas and beans, is taken as equivalent to temperate grassland as defined by Cleveland et al. [1999].

[15] Nitrogen is redistributed in the landscape and across national boundaries with food and feed transfers as well as plant and seed transfers. Boyer et al. [2002] have estimated the food and feed transfer flux of nitrogen for the eastern United States by considering human and animal demand relative to production within the region. In this study takes an alternative approach and uses commodity trade data to estimate the nitrogen export or import for the United Kingdom. The tonnage of imports versus exports was compared for: wheat, barley, oats, maize, linseed, oilseed, sugar, potatoes, vegetables, flowers, fruit, cattle, sheep, pigs, chickens, butter, cheese, cream and milk (powdered and condensed). The balance of trade in food and feedstuff commodities was available as the average for 1979-1981 and for 2005 (MAFF, Agriculture in United Kingdom, 1982; DEFRA, Agriculture in the United Kingdom, 2006). The balance of trade in each chosen commodity was converted to a balance of nitrogen trade using typical nitrogen contents of common foodstuffs [Rossi et al., 2004]. The import or export of plant and seeds is not recorded in UK agriculture commodity records.

[16] Consistent atmospheric deposition records for the United Kingdom have only been maintained since 1986 [Fowler et al., 2005]. Records of acidifying compound emissions $\left(\mathrm{NO}_{\mathrm{y}}, \mathrm{SO}_{\mathrm{x}}, \mathrm{HCl}\right.$ and $\left.\mathrm{HF}\right)$ are available back to 1970 [Dore et al., 2007], these records of nitrogen gas emissions include those from agriculture and denitrification from the land surface. Deposition of total nitrogen oxides and ammonia $\left(\mathrm{NH}_{\mathrm{x}}\right)$, and emissions of total nitrogen oxides and ammonia are reported for 1986 to 2001 by Fowler et al. [2005]. The records of atmospheric deposition were extended to 2005 by reference to Lawrence et al. [2007]. The records of emissions were extended to 2005 by reference to Dore et al. [2007] and to Choudrie et al. [2008].

[17] Figures for the use of synthetic inorganic fertilizer in the United Kingdom were derived for the period 1974 to 2005 from surveys published by the Fertiliser Manufacturers Association and the Environment Agency of England and Wales [British Survey of Fertiliser Practice, 2007]. The vast majority of animal wastes in the United Kingdom are returned to the land on the same farm as they are produced and therefore represent an internal transfer with no loss from the system, further it is assumed that there is no net transfer between catchments. Irrigation water contains a small amount of nitrate and DON and so also represents an input. However, the irrigation flux is small and is assumed to be an internal transfer. The UK Government banned the burning of crop residues in 1993 and most residues are now left in field after harvest. However, the extent to which this will impact the terrestrial nitrogen budget is currently not known values of what this represents are not available. Smil [1999] recognized that records of crop residues are not maintained by any country and so this cannot be estimated here. Therefore, the study could calculate a flux record for total $\mathrm{N}$ deposition; $\mathrm{N}$ oxide emissions; $\mathrm{NH}_{3}$ emissions; direct inputs of $\mathrm{N}_{\mathrm{r}}$ via waste effluent; direct sewage inputs; biological fixation of $\mathrm{N}$; food and feed transfers; inputs of inorganic fertilizer; all in comparison to the total dissolved $\mathrm{N}_{\mathrm{r}}$ and PON flux.

[18] The fluvial flux data as calculated above are for Great Britain and not for the United Kingdom, i.e., the area of Northern Ireland is not included. Thus, all annual data are 


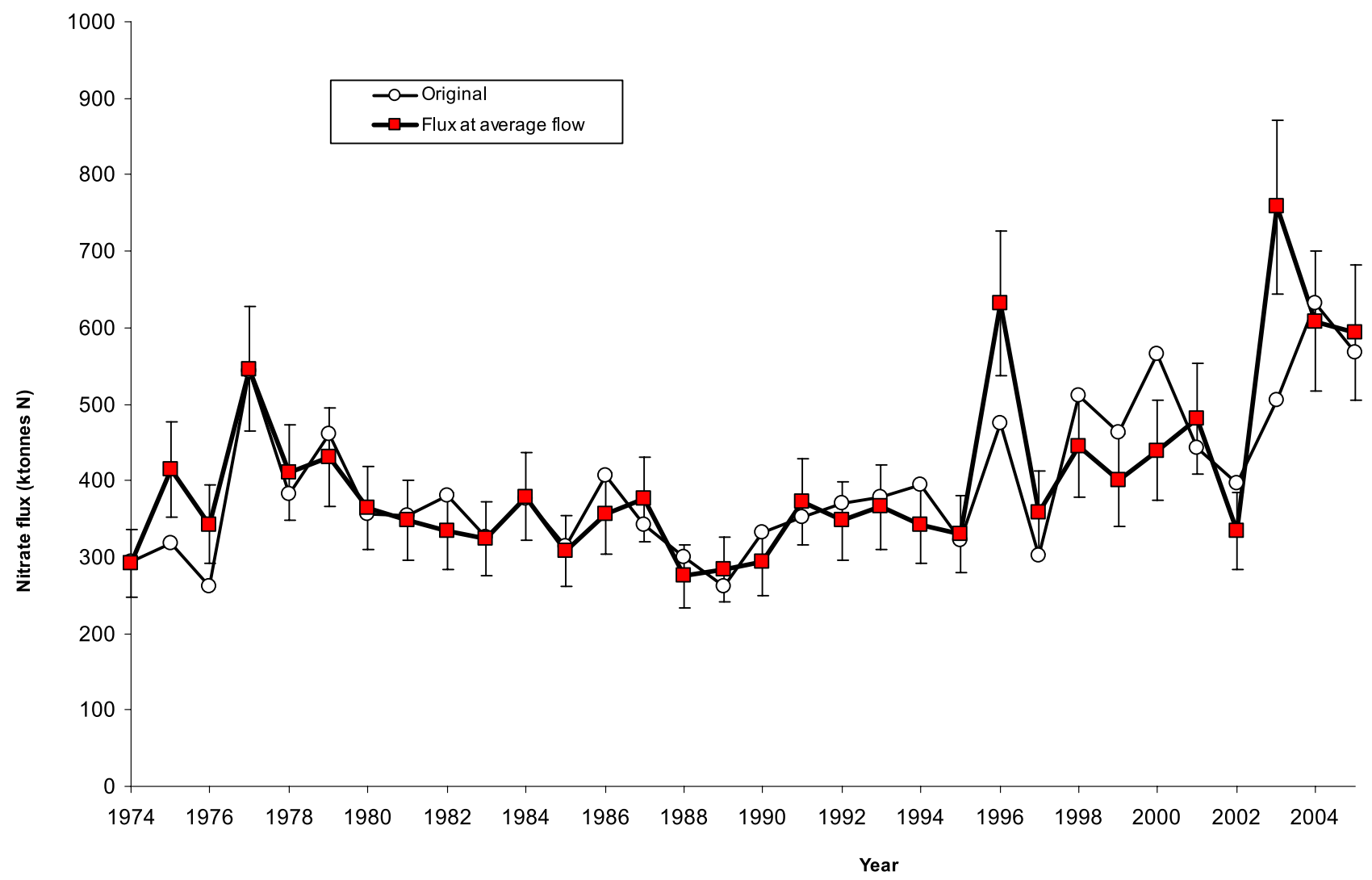

Figure 2. The time series of calculated nitrate $\mathrm{N}$ flux from Great Britain over the study period, 19742005 .

corrected for the area of Northern Ireland. Further, most of the comparative nitrogen fluxes listed above are from UK Government and other published data sources, and as such, the flux was not calculated within this study. Therefore, the original data were not available to this study, and so this study has had to accept the error estimation from each individual source. In some cases, no error or uncertainty estimate is given; in other cases the error estimate is not credible. For example, the OSPAR Commission [2007] report the upper and lower limit of direct flux of nitrate from the United Kingdom in 2005 as between 210.5 and $210.9 \mathrm{kt} \mathrm{N} \mathrm{a}^{-1}$, an error of only $0.2 \%$. In other cases, although the reported flux error is given as a range, it is not always clear what this range actually represents (e.g., minimum-maximum, interquartile range or confidence intervals) making it impossible for them to be considered here. Therefore, only the error estimated for the fluvial flux is included here. The other comparative fluxes considered in this study are reported as reported in their original source without error or uncertainty estimates. For a discussion of the uncertainty in national-scale $\mathrm{N}$ budgets refer to Kroeze et al. [2003].

\section{Results}

\subsection{Analysis of Fluvial Nitrogen Flux Errors}

[19] The error associated with sampling frequency is expressed as the mean percentage difference between
200 individual sets of 12 random flux calculations and the flux calculated based upon all 158 samples at the site with the highest sampling frequency in any one year. The flux based upon all 158 samples was $1267 \mathrm{t} \mathrm{N} \mathrm{a}^{-1}$ while the mean value based upon the 200 subsets of 12 data points was $1134 \mathrm{t} \mathrm{N} \mathrm{a}^{-1}$. This represents a mean percentage error of $\pm 10.6 \%$. For the DOC flux and hence the DON flux, Worrall and Burt [2007] estimated a mean percentage error of $\pm 14 \%$.

[20] The area of each HMS region covered by catchments draining to sampling sites varies between 23 and $85 \%$ of the individual regions, with Scotland having the lowest area covered, mainly due to the poor representation of west coast catchments within the HMS. Conversely, the best coverage is achieved where the region is dominated by a single large river (e.g., River Thames in the Thames region). The error associated with upscaling from catchment export estimates to the regional and national scales was estimated as half the percentage difference between the values estimated from the fifth and 95th percentile exports for each region. This gives an error due to upscaling of $\pm 31 \%$. As this is a larger source of error, this is the one used in the rest of the study.

[21] The source of error due to estimations of the carbon and nitrogen content of dissolved and particulate organic matter has already been discussed above, and the effect of this variation on calculated fluxes is reported below. 


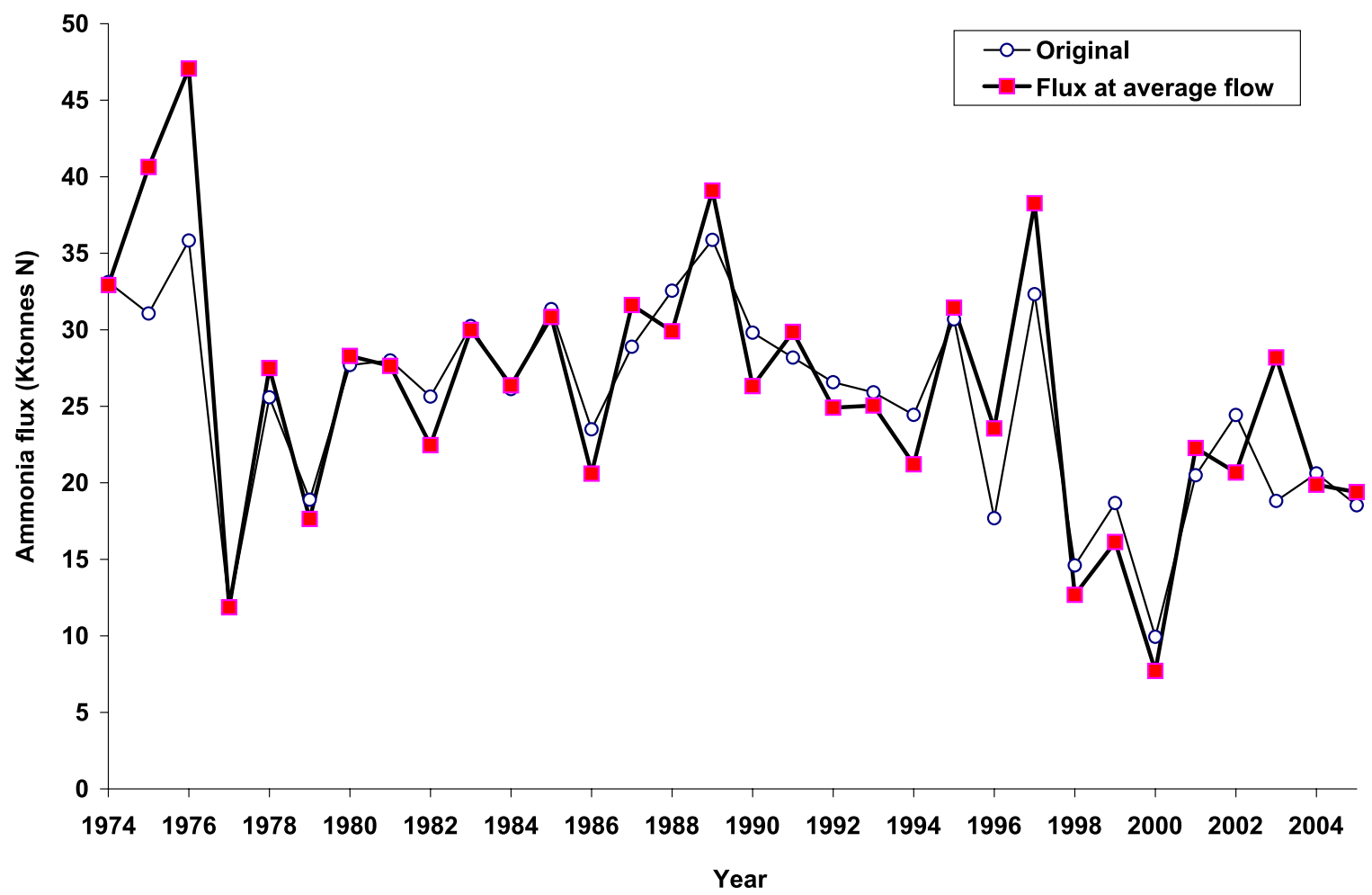

Figure 3. The time series of calculated ammoniacal $\mathrm{N}$ flux from Great Britain over the study period, $1974-2005$.

\subsection{Total Export From Great Britain}

[22] The calculated nitrate flux from Great Britain varied from 230 to $631 \mathrm{kt} \mathrm{N} \mathrm{a}^{-1}$. With flow correction, the calculated nitrate flux at average flow varied from 275 to $758 \mathrm{kt} \mathrm{N} \mathrm{a}^{-1}$ (Figure 2). The time series of the flux without flow correction shows a significant peak in 1977 followed by a decline to 1989 but then increases through the 1990s to peak in 2004. In the case of both 1977 and 2004, peak calculated fluxes followed a very dry previous year. After flow correction the decline in nitrate flux after 1977 and the rise after 1989 are both diminished. However, the peaks in 1977, 1996, and 2003 are enhanced. The time series of nitrate flux implies a steady background flux of nitrate enhanced in or immediately after severe droughts. Over the study period, the flow-corrected flux showed a significant increase of $5.4 \mathrm{kt} \mathrm{N} \mathrm{a}^{-1}\left(r^{2}=0.2, n=31\right)$.

[23] The flux of nitrite (time series not shown) varies from 3.9 to $8.4 \mathrm{kt} \mathrm{N} \mathrm{a}^{-1}$ and between 4.1 to $9.4 \mathrm{kt} \mathrm{N} \mathrm{a}^{-1}$ when flow corrected. The nitrite flux represents between just 1 and $2 \%$ of the nitrate flux. The calculated nitrite time series mimics nitrate with peaks in 1977 and 1996 but with no distinct peak in 2003. The clear link between nitrate and nitrite flux is unsurprising and is in line with expectations for surface waters under normal redox and $\mathrm{pH}$ conditions [Patrick and Mahapatra, 1968].

[24] The ammoniacal $\mathrm{N}$ flux varies from 9.9 to $35.8 \mathrm{kt} \mathrm{N}$ $\mathrm{a}^{-1}$ or between 7.7 and $47.0 \mathrm{kt} \mathrm{N} \mathrm{a}^{-1}$ when flow corrected. The time series of ammoniacal nitrogen flux is shown in Figure 3. As with nitrate, significant peaks are evident in the years 1977 and 2003. However, peaks also occur in 1989 and 1997. Furthermore, both the corrected and uncorrected flux time series show a distinct decrease over the study period. For both time series this decline is statistically significant with an average annual decline of $0.36 \mathrm{kt} \mathrm{N}$ $\mathrm{a}^{-1}\left(r^{2}=0.18, n=31\right)$.

[25] The flux of DOC varied from 621 to $1994 \mathrm{kt} \mathrm{C} \mathrm{a}^{-1}$. With flow correction the variation was between 811 and $1922 \mathrm{kt} \mathrm{C} \mathrm{a}^{-1}$. The time series of the DOC flux (Figure 4) shows a distinct increase over the study period. For the flow-corrected series the increase in DOC flux is statistically significant at $11 \mathrm{kt} \mathrm{C} \mathrm{a}^{-1}\left(r^{2}=0.27, n=30\right)$. The DON flux is also shown in Figure 4 and varies from 76 to $243 \mathrm{kt}$ $\mathrm{N} \mathrm{a}^{-1}$. Again, the time series of DON shows a significant increase of $1.6 \mathrm{kt} \mathrm{N} \mathrm{a}^{-1}\left(r^{2}=0.27, n=30\right)$.

[26] Suspended sediment concentrations were only available from 1992 but given best estimates of the carbon and nitrogen contents, the PON flux varies between 8 and $121 \mathrm{kt}$ $\mathrm{N} \mathrm{a}^{-1}$ and between 11 and $121 \mathrm{kt} \mathrm{N} \mathrm{a}^{-1}$ when flow corrected (Figure 5). The estimated flux of PON shows no significant trend between 1992 and 2005.

[27] The total dissolved nitrogen flux from Great Britain (nitrate, nitrate, ammoniacal $\mathrm{N}$ and $\mathrm{DON}$ ) is estimated to vary between 392 and $900 \mathrm{kt} \mathrm{N} \mathrm{a}^{-1}(470-980 \mathrm{kt} \mathrm{N} \mathrm{a}$ when flow corrected) (Figure 6). The total calculated nitrogen flux (i.e., including PON), the flow corrected annual flux values vary from 508 to $1004 \mathrm{kt} \mathrm{N} \mathrm{a}^{-1}$ (Figure 6). The overall time series of total nitrogen showed a significant increase of $6.3 \mathrm{kt} \mathrm{N} \mathrm{a}^{-1}\left(r^{2}=0.22, n=30\right)$. Although this significant increase could be due to the fact that two of the identified drought-related peaks occur 


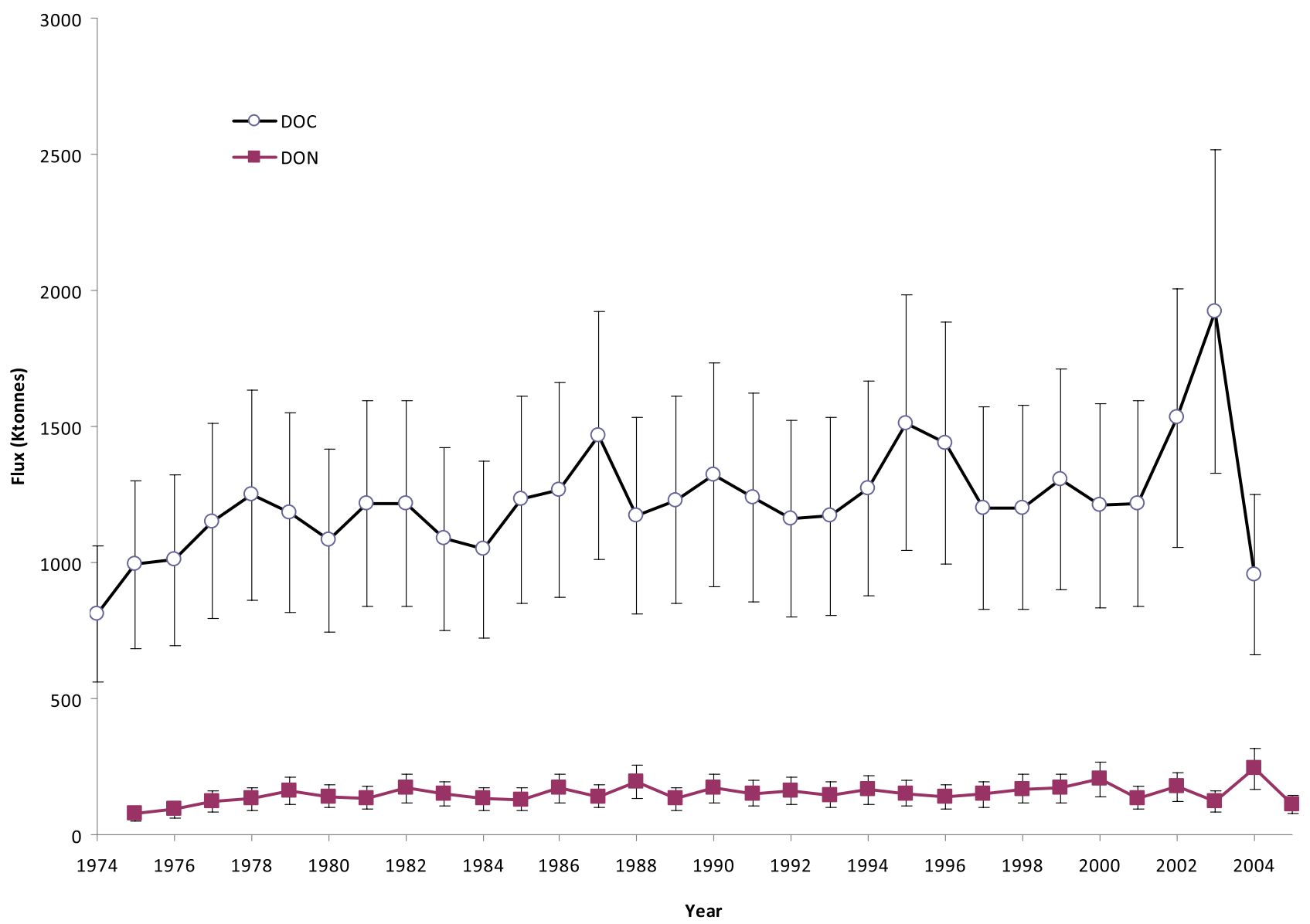

Figure 4. The time series of calculated DOC and DON flux from Great Britain over the study period, $1974-2005$.

toward the end of the series, there does appear to be a background rise in total nitrogen export driven by increases in both nitrate and DON fluxes. The average composition of the total nitrogen flux is: $63 \%$ nitrate, $24 \%$ DON, $8 \%$ PON, $4 \%$ ammoniacal $\mathrm{N}$ and $1 \%$ nitrite.

[28] The fluxes of nitrogen species reported are compared with similar estimates from other western European basins in Table 1. The basins chosen are already at the higher end of ranges reviewed by Harrison et al. [2005], Beusen et al. [2005], Meybeck and Ragu [1995], and Alexander et al. [1998]. This comparison would, therefore, suggest that the United Kingdom is indeed a "hotspot" of dissolved inorganic nitrogen $(\mathrm{DIN}=$ nitrate + nitrite + ammonia $)$ and dissolved organic nitrogen (DON).

[29] The total nitrogen flux estimated here is considerably higher than the estimate of $490 \mathrm{kt} \mathrm{N} \mathrm{a}^{-1}$ made by Littlewood and Marsh [2005] and the range (280-432 $\left.\mathrm{kt} \mathrm{N} \mathrm{a}^{-1}\right)$ published by the OSPAR Commission for the period 1990-2005. There are two main reasons for these disparities: First, the earlier estimates do not include an estimate of DON or PON even though these represent approximately $32 \%$ of the total nitrogen flux. Second, the method used here to upscale the flux accounts for the unsampled areas which are not captured by the HMS network of monitored catchments, whereas the earlier estimates do not.

\subsection{Comparison of the Fluvial Flux With Other Nitrogen Fluxes}

[30] Input of inorganic fertilizer to the soils of Great Britain is by far the largest of the inputs considered. This peaked in 1987 at $1650 \mathrm{kt} \mathrm{N} \mathrm{a}^{-1}$ and has been declining since, although the decline has leveled off and applications have not quite returned to 1974 levels (Figure 7). The atmospheric deposition of total nitrogen has been declining since its peak in $1994\left(246 \mathrm{kt} \mathrm{N} \mathrm{a}^{-1}\right)$ and by 2005 it was below values at the time of first reporting in 1986. Emissions of nitrous oxide from agriculture have declined consistently from the start of the record in 1990 to the present. In contrast, total nitrous oxide emissions declined from a peak in 1989 to a minimum in 2000 but have subsequently risen [Fowler et al., 2005]. Agricultural ammonia emissions have also declined from the start of the record in 1990 to a minimum in 2003 but have since risen. The direct fluxes of nitrogen from sewage and industrial wastes appear to have declined across the study period by almost $50 \%$ from a high of 326 to $165 \mathrm{kt} \mathrm{N} \mathrm{a}^{-1}$ in 2003. This decline can be ascribed to improved wastewater treatment provision, implemented in part as a response to the Urban Wastewater Treatment Directive (91/271/EEC [European Commission, 1991]). Estimated biological fixa- 


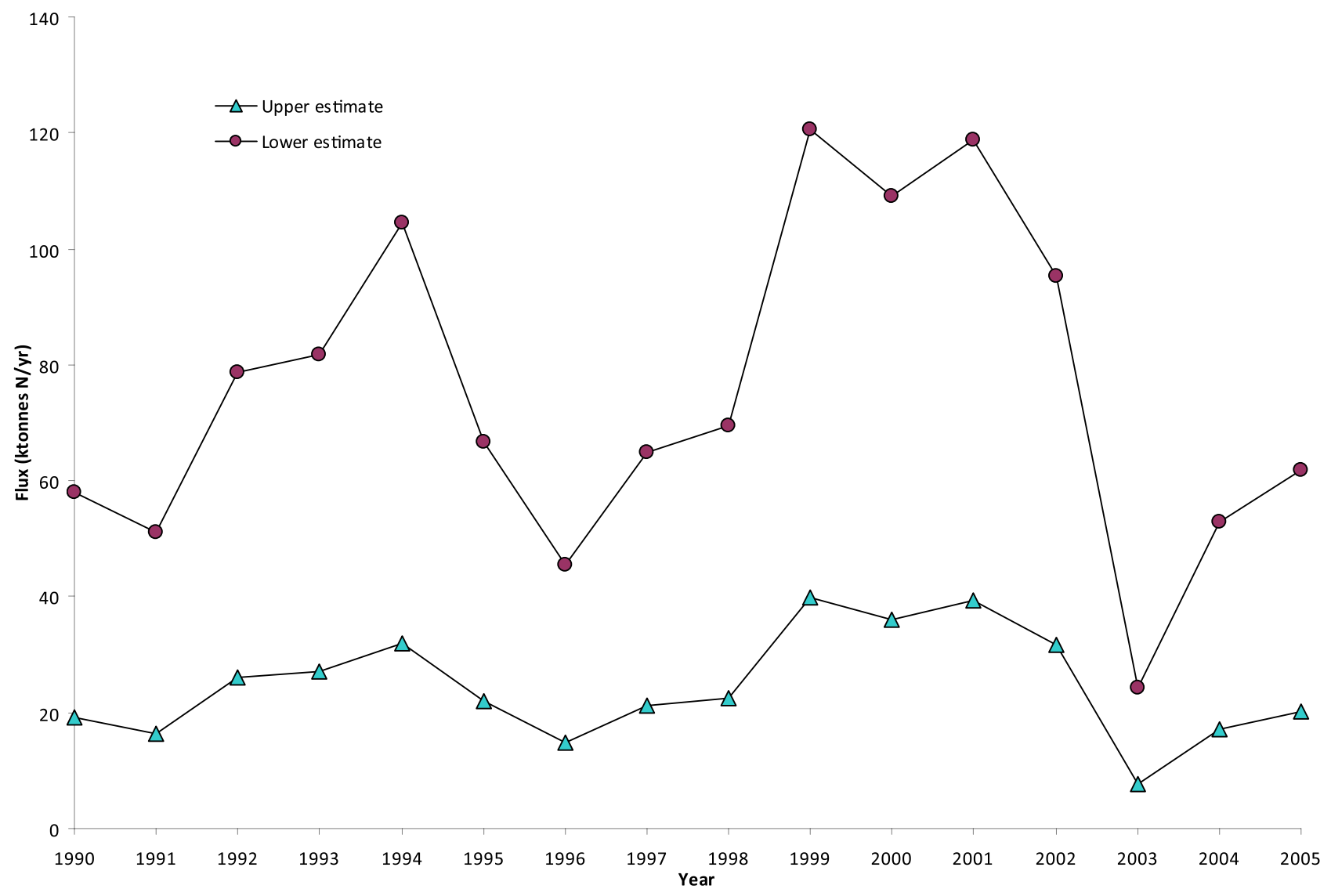

Figure 5. The time series of calculated PON flux from Great Britain over the study period, 1974-2005. The upper and lower limits are based upon the range of organic carbon and $\mathrm{C} / \mathrm{N}$ contents of suspended sediment discussed in the text.

tion of nitrogen has fallen slightly over the study period as the proportion of the United Kingdom given over to temporary grass has declined. The United Kingdom is net importer of food and feedstuffs and in terms of nitrogen this appears to have risen over the study period. Although exports, in terms of tonnage, have risen, the trade composition has shifted to increased export of low nitrogen goods (e.g., wheat) but increased importation of high nitrogen goods (e.g., beef).

[31] Total N flux was only calculated from 1990 onward when all data sets were available. The calculations suggest that Great Britain was a net sink of reactive nitrogen over this period (outputs < inputs). The value of the net sink varied from a high of $1142 \mathrm{kt} \mathrm{N} \mathrm{a}^{-1}$ in 1990 to a low of $420 \mathrm{kt} \mathrm{a}^{-1}$ in 2003, that is between 1.8 and $5 \mathrm{t} \mathrm{N} \mathrm{km}^{-2} \mathrm{a}^{-1}$. It its difficult to compare this range with to other national figures or figures for a region of similar scale. Kroeze et al. [2003] have given a figure of $469 \mathrm{kt} \mathrm{N}$ accumulating in or denitrifying from Dutch soils in 1995; this is $10.5 \mathrm{t} \mathrm{N} \mathrm{km}^{-2}$ $\mathrm{a}^{-1}$, but they suggest that the majority of this is lost via denitrification. The trend in the total $\mathrm{N}$ budget is significant with an average decline net sink in the $\mathrm{N}$ budget of $-32 \mathrm{kt}$ $\mathrm{N} \mathrm{a}^{-1}$. The total fluvial flux of $\mathrm{N}_{\mathrm{r}}$ as proportion varied from 21 to $52 \%$ of the $\mathrm{N}$ inputs with this proportion significantly increasing at $1.4 \% \mathrm{a}^{-1}$. Likewise the fluvial flux is an increasing proportion of the output being $41 \%$ in 1990 but $60 \%$ by 2005 (Figure 8 ). Conversely, the emissions of $\mathrm{Nr}$ have varied between 47 and $62 \%$ of the inputs but there is no significant trend on this proportion with time of the study period.

\section{Discussion}

[32] This study presents evidence to suggest that for Great Britain the difference between inputs and outputs of reactive nitrogen $\left(\mathrm{N}_{\mathrm{r}}\right)$ is decreasing. It is difficult to account accurately for every single component of such a budget and, indeed, the study has already pointed out that neither crop residues or animal wastes have been considered here. Throughout the study the component that has been missing is the denitrification to $\mathrm{N}_{2}$ from both the terrestrial and aquatic systems. The difference between the inputs and outputs of $\mathrm{N}_{\mathrm{r}}$ would mean that denitrification to $\mathrm{N}_{2}$ would have to represent, at the very least, a net loss of nitrogen of $420 \mathrm{kt} \mathrm{N} \mathrm{a}^{-1}$ to turn the Great Britain into a net source. Similarly, any missing input or inputs would have to be increasing at a rate greater than $32 \mathrm{kt} \mathrm{N} \mathrm{a}^{-1}$ in order to reverse the current trend.

[33] The denitrification loss can be both terrestrial and aquatic. The processing of nitrogen species in streams was not considered by Smil [1999] and Boyer et al. [2002, 2006] but was by Marsh [1980]. Potential in-stream nitrogen 


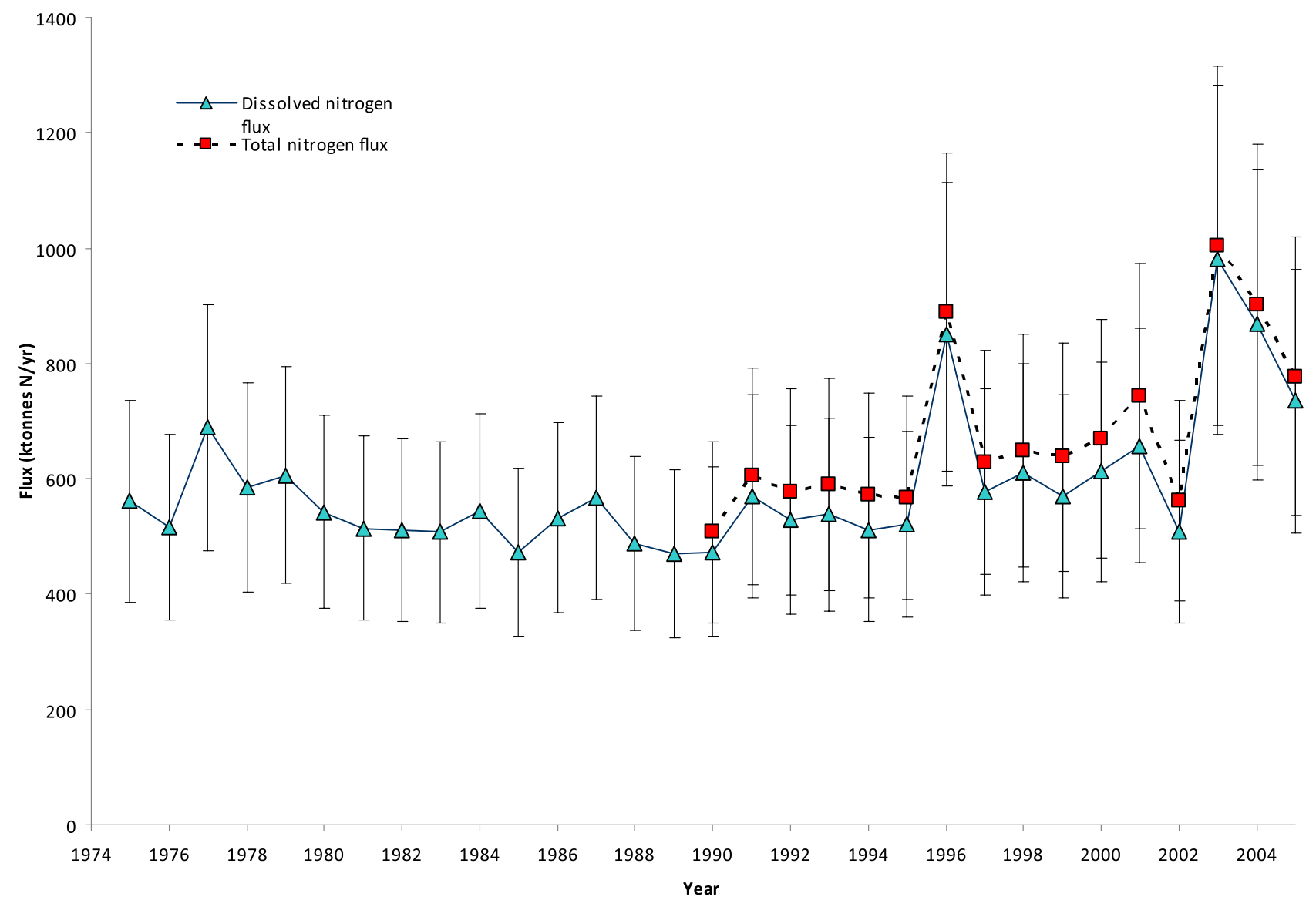

Figure 6. The time series of calculated dissolved and total nitrogen flux from Great Britain over the study period, 1974-2005.

losses include could be lost from catchment rivers through immobilization in the stream biomass or and denitrification to the atmosphere; stream processes can also be a source of nitrogen as PON and DON are mineralized. The net size of this loss or production overall has not been calculated. Kroeze et al. [2003] have reviewed N retention proportions in surface waters and taking their figures for streams rather than lakes the variation in the proportion of retention is between 11 and 50\% of the input. Seitzinger et al. [2002] have proposed an empirical relationship relating $\% \mathrm{~N}$ removed to depth of water body and residence time. Applying this emprirical relationship to the relatively unimpeded rivers of the United Kingdom suggests $\mathrm{N}$ removal of between 6 and 27\%. Given the fluvial fluxes reported in this study this range of $\% \mathrm{~N}$ removal in-stream would mean $\mathrm{N}_{\mathrm{r}}$ losses from soil of between 479 (assuming $6 \%$ loss in the year with the lowest fluvial $\mathrm{Nr}$ flux) and 1356 (assuming 27\% loss in the year of the highest fluvial $\mathrm{Nr}$ flux) $\mathrm{kt} \mathrm{N} \mathrm{a}^{-1}$. Given allowance for these levels of removal means that in the latter case that fluvial $\mathrm{N}_{\mathrm{r}}$ flux would be between 105 and $135 \%$ of $\mathrm{N}$ inputs in that year. Van Breemen et al. [2002] suggest that terrestrial dentrification is twice as large as aquatic denitrification $(35 \%$ compared to $16 \%$ of inputs), at a rate of $35 \%$ of inputs this would mean that terrestrial denitrification would be between 831 and $668 \mathrm{kt} \mathrm{N} \mathrm{a}^{-1}$.

Table 1. Comparison of Export Values of Nitrogen and Carbon Species for Major Western European Rivers With Values Derived for Great Britain From This Study ${ }^{\mathrm{a}}$

\begin{tabular}{|c|c|c|c|c|c|c|}
\hline River Basin & $\begin{array}{c}\text { Size } \\
\left(\mathrm{km}^{2}\right)\end{array}$ & $\begin{array}{c}\text { DIN } \\
\left(\mathrm{kg} \mathrm{N} \mathrm{km}^{-2} \mathrm{a}^{-1}\right) \\
\end{array}$ & $\begin{array}{c}\mathrm{DOC} \\
\left(\mathrm{kg} \mathrm{C} \mathrm{km}^{-2} \mathrm{a}^{-1}\right) \\
\end{array}$ & $\begin{array}{c}\text { DON } \\
\left(\mathrm{kg} \mathrm{N} \mathrm{km}^{-2} \mathrm{a}^{-1}\right) \\
\end{array}$ & $\begin{array}{c}\text { POC } \\
\left(\mathrm{kg} \mathrm{Nm}^{-2} \mathrm{a}^{-1}\right) \\
\end{array}$ & $\begin{array}{c}\mathrm{PON} \\
\left(\mathrm{kg} \mathrm{N} \mathrm{km}^{-2} \mathrm{a}^{-1}\right) \\
\end{array}$ \\
\hline Danube & 817,000 & & $1152(2)$ & $90(3)$ & $1000(4)$ & $100(4)$ \\
\hline Elbe & 148,000 & $795(1)$ & $753(2)$ & & $300(4)$ & \\
\hline Po & 70,000 & & 3046 (2) & $263(3)$ & $4600(4)$ & $600(4)$ \\
\hline Rhine & 164,500 & 2200 & $1388(2)$ & & $900(4)$ & $100(4)$ \\
\hline Seine & 7,390 & 1365 (1) & $917(2)$ & $113(3)$ & $500(4)$ & $100(4)$ \\
\hline Weser & 45,470 & 1205 (1) & & & $700(4)$ & $100(4)$ \\
\hline This study & 244,000 & $1279-3211$ & $2545-8173$ & $310-997$ & $539-2693$ & $99-352$ \\
\hline
\end{tabular}

${ }^{a}$ Numbers in parentheses are the sources of the comparative data: 1, Meybeck and Ragu [1995]; 2, Alexander et al. [1998]; 3, Harrison et al. [2005]; and 4, Beusen et al. [2005]; italic values are model results based on the work by Meybeck and Ragu [1995]. 


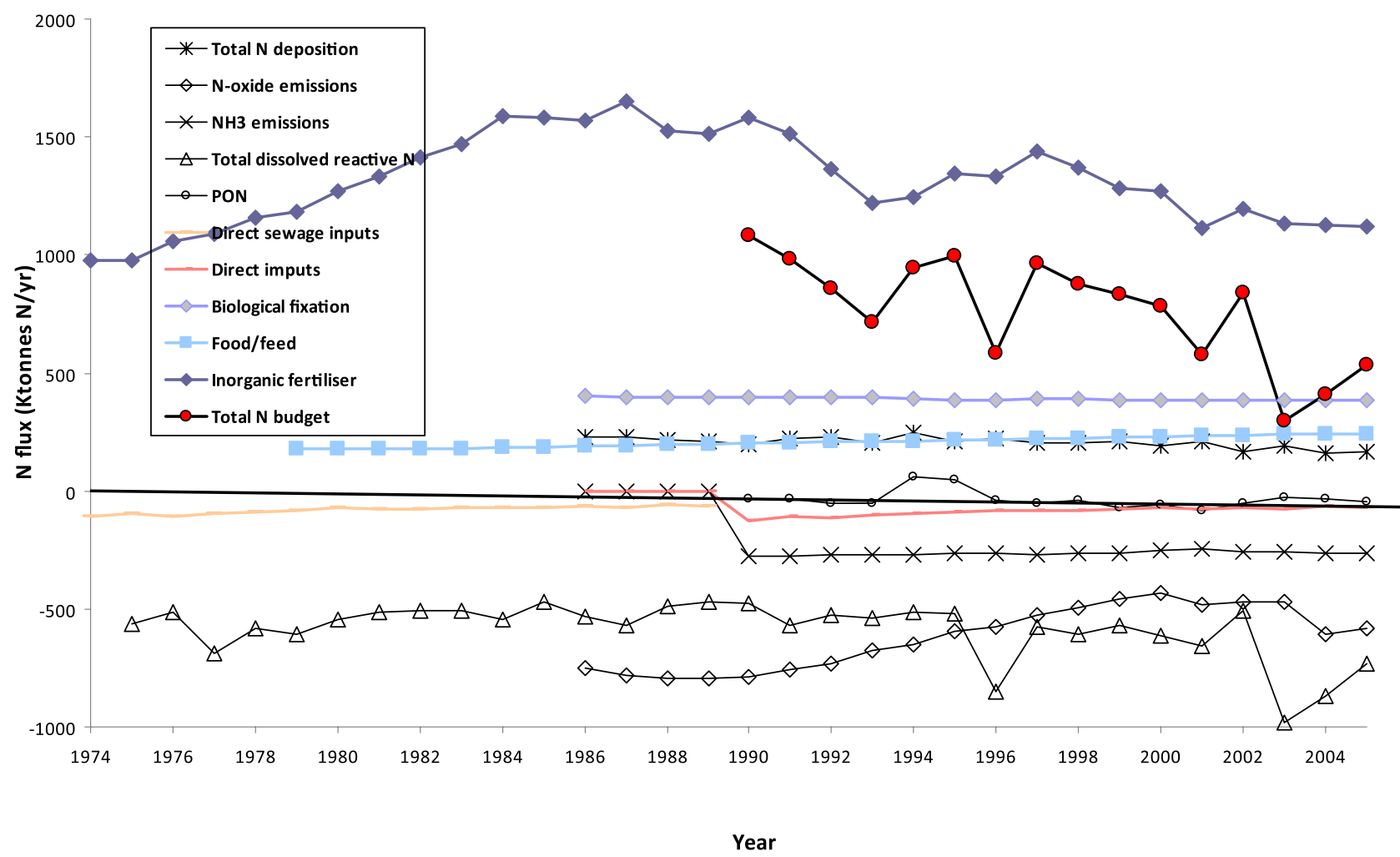

Figure 7. Comparison of terrestrial nitrogen inputs and outputs.

[34] An additional omission is any consideration of the fate of the extra nitrogen removed from the direct wastewater fluxes. These fluxes declined by approximately $160 \mathrm{kt}$ $\mathrm{N} \mathrm{a}^{-1}$ over the course of the study period, largely through improved wastewater treatment provision. Some of this decline may be accounted for by denitrification and ammonia volatilization during sewage treatment but some will represent a diversion of nitrogen to land via sewage sludge. These processes have not been accounted for in the calculations. The study predicts that Great Britain is a net sink of nitrogen which is not surprising and would be expected in comparison with other developed agricultural countries [Parris, 1998], but where is this nitrogen going? First, this nitrogen could be stored in the UK terrestrial biosphere in land not in production. Second, the consideration of nitrogen retention in streams would shrink the size of sink by up to $90 \%$. Third, this study has not considered the change in storage in groundwater and surface waters, if it is considered that significant groundwater bodies cover between 10 and $50 \%$ of the UK land area and that this groundwater body represents an equivalent depth of water between 1 and $10 \mathrm{~m}$ then a $1 \mathrm{mg} \mathrm{N} \mathrm{L}^{-1}$ increase in average groundwater concentration would represent an additional $300 \mathrm{kt} \mathrm{N}$ of storage.

[35] The clear peaks in the record of the fluvial nitrate time series are associated with drought years. In principle, this could simply be a storage effect with reduced $\mathrm{N}$ transfers in the drought year resulting in increased nitrate available for transport in the subsequent year. To test this hypothesis nitrate flux was regressed against total British river flow in the current year and the total flow in the previous year. In each case the flow record was $\mathrm{z}$ transformed so that dry years represent $\mathrm{z}$ values of less than 1 . This simple regression showed no significant effect of the previous year's flow as would be expected if there were a storage effect. A lack of a storage effect implies that only the severest droughts cause peaks in the subsequent year and that additional nitrate is produced during these droughts. If air-dried soils are rewetted, a pronounced $\mathrm{N}$ and $\mathrm{C}$ mineralization flush is frequently observed [e.g., Powlson and Jenkinson, 1976; Haynes and Swift, 1989]. This phenomenon is sometimes called the Birch effect [after Birch, 1960], and it is thought to occur due a combination of (1) the death of microorganisms from moisture stress followed by remineralization on rewetting and (2) the physical disturbance induced by the drying and wetting event itself. For the DON flux the effect of the previous year's flow is insignificant at the 95\% level $(p=0.07)$ and the coefficient of lagged $\mathrm{z}$ transformed flow is negative, i.e., consistent with drought years having a positive effect upon the magnitude of the subsequent year's flux. For ammoniacal $\mathrm{N}$ flux, there was no significant effect of the previous year's flow. The additional production of DOC, and thus DON, during severe droughts may have been the result of declines in the water table leading to increased oxidation in soils, and new enzymatic processes being triggered [Freeman et al., 2001] or changes in solubility [e.g., Clark et al., 2005]. Most models of nitrogen fluxes at different scales (empirical or mechanistic) do not explicitly consider any influence of drought on the predicted flux. Empirical models which are calibrated on drought years may implic- 


\section{Outputs}
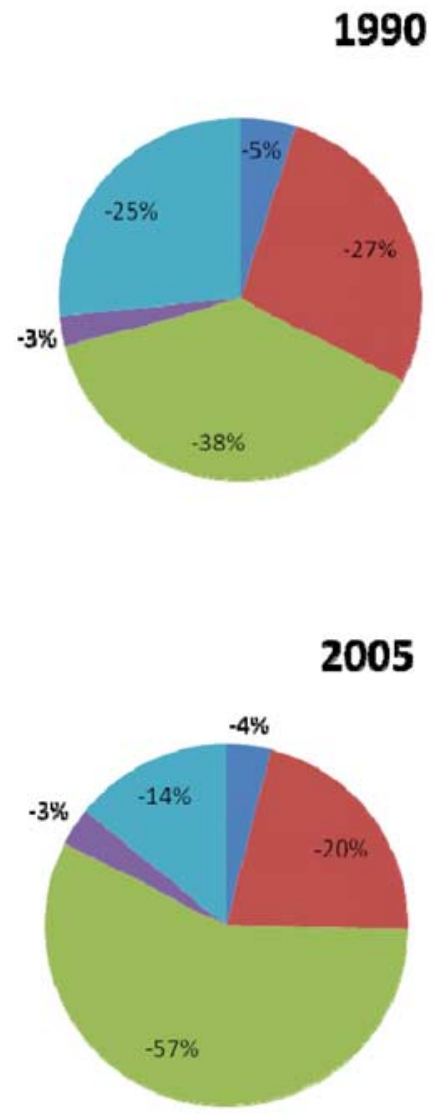

Inputs

1990

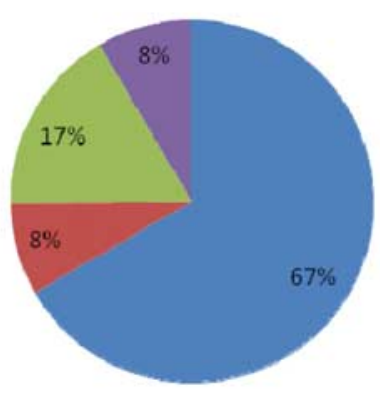

artiliser

apric. N1 13 emissions

m Total dissolved $\mathrm{N}$

a PON

m Direct waste inputs
- Tolal $\mathbf{N}$ deposition

- Bological fixation

Food \& feedstuffs

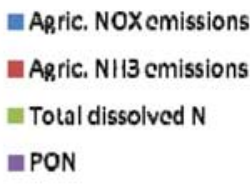

Direct wasle inpuls

\section{5}

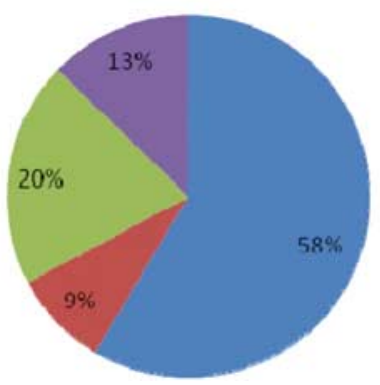

Eertiliser

- Total N dsposition

Bolopical fixation

a Food \& fecedstuffs

Figure 8. Change in the proportion of each nitrogen species comparing the inputs and outputs from 1990 to 2005.

itly (and erroneously) incorporate phenomena, such as the additional production of nitrate.

[36] The increases in fluvial flux of nitrogen over the study period highlights a number of problems in the prediction of land to ocean nitrogen transfers on the basis of land use and other nitrogen exchanges [e.g., Seitzinger et al., 2005]. Most approaches either use data from a range of years to predict a fixed value of flux and a fixed distribution of nitrogen species or use values in 1 year to predict the fluxes in another year. Applying either approach to the fluvial flux record from the United Kingdom would result in an inverse relationship between inputs and outputs, thus forcing a conclusion that decreasing inorganic nitrogen inputs leads to an increased fluvial flux of nitrogen. The explanation to this apparent paradox lies in the processes which lead to the translation of inputs to outputs. These processes are many and complex and operate of different timescales, some of which have response times of the order of decades. A concurrent increase in the fluvial flux of nitrogen and a decrease in total nitrogen inputs suggests that there is temporal disconnection between the inputs and the outputs. So, what is causing the observed rise in total dissolved nitrogen flux from Great Britain? First, the rise in DON is being driven by increased dissolved organic matter concentrations in runoff from organic rich soils, a phenomena that has been widely observed in boreal and subboreal regions across the northern hemisphere [e.g., Monteith et al., 2007]. The reasons for the increase in DOC and thus in DON have been widely debated and there is good reason to believe that concentrations will continue to rise with ongoing climate change [Worrall et al., 2007b]. There are a number of potential explanations for the increase in nitrate transfers. First, the release of nitrate to surface waters following an increase in inputs is often delayed by long residence time flow paths such as those which occur in groundwater. Second, significant long-term stores of organic nitrogen, such as those in pasture soils have been released by ploughing resulting in large increases in the nitrate leaching, often over several decades after cultivation [Whitmore et al., 1992; Worrall and Burt, 2001]. Third, many stores within the terrestrial system have now become "nitrogen saturated" (a condition in which nitrogen inputs are not retained in the system) resulting in an export of excess inputs. Nitrogen saturation has been observed in forest ecosystems [e.g., Aber et al., 1989] but could also occur in fluvial systems as rivers have a finite capacity to absorb and process nitrogen. Thus, although inputs to the fluvial system have increased, residence times 
have not, resulting in decreased uptake and denitrification as a fraction of the loads transported. The observed trend in flux could mean that despite decreasing inputs from the atmosphere and from inorganic fertilizers the output of nitrogen could continue to rise for some time to come due to combination of lag, storage and saturation effects.

\section{Conclusions}

[37] This study suggests that, in recent years, the total nitrogen flux from British rivers has varied between 508 and $1004 \mathrm{kt} \mathrm{N} \mathrm{a}^{-1}$ with an estimated dissolved nitrogen contribution of up to $980 \mathrm{kt} \mathrm{N} \mathrm{a}^{-1}$ at equivalent average flow. The dominant nitrogen species was nitrate $(69 \%$ of the average annual total flux). Nitrate, nitrite and DON all showed a significant increase over the 31 years of the study. The ammoniacal $\mathrm{N}$ flux showed a significant decline. Overall, there has been a significant annual increase in the total dissolved nitrogen flux of $6.3 \mathrm{kt} \mathrm{N} \mathrm{a}^{-1}$. The time series of total nitrogen flux shows peaks in flux shortly after periods of severe drought. These peaks are consistent with additional production of nitrate rather than storage effects. A significant increase in the fluvial flux of nitrogen must be viewed in the context of significant declines in inputs of inorganic fertilizer and atmospheric deposition. The disconnection between inputs and fluvial outputs seriously compromises simple approaches to predicting flux to the oceans and implies that fluvial fluxes may continue to increase even with continued long-term reductions in inputs.

\section{References}

Aber, J. D., K. J. Nadelhoffer, P. Steudler, and J. M. Melillio (1989), Nitrogen saturation in northern forest ecosystems, BioScience, 39, 378-386, doi: $10.2307 / 1311067$.

Alexander, R. B., J. R. Slack, A. S. Ludtke, K. K. Fitzgerald, and T. L. Schertz (1998), Data from selected U.S. Geological Survey national stream water-quality monitoring networks, Water Resour. Res., 34, 2401-2405, doi:10.1029/98WR01530.

Bellamy, D., and P. Wilkinson (2001), Ospar 98/3: An environmental turning point or a flawed decision?, Mar. Pollut. Bull., 42, 87-90, doi:10.1016/S0025-326X(00)00121-1.

Betton, C. W., B. W. Webb, and D. E. Walling (1991), Recent trends in $\mathrm{NO}_{3}-\mathrm{N}$ concentration and loads in British rivers, in Sediment and Stream Water Quality in a Changing Environment: Trends and Explanation, edited by N. E. Peters and D. E. Walling, IAHS AISH Publ., 203, $169-180$.

Beusen, A. H. W., A. L. M. Dekkers, A. F. Bouwman, W. Ludwig, and J. A. Harrison (2005), Estimation of global river transport of sediments and associated particulate C, N, and P, Global Biogeochem. Cycles, 19, GB4S05, doi:10.1029/2005GB002453.

Birch, H. F. (1960), Nitrification in soils after different periods of dryness, Plant Soil, 12, 81-96, doi:10.1007/BF01377763.

Boyer, E. W., C. J. Goodale, N. A. Jaworski, and R. W. Howarth (2002), Anthropogenic nitrogen sources and relationships to riverine nitrogen export in the northeastern USA, Biogeochemistry, 57-58, 137-169, doi:10.1023/A:1015709302073.

Boyer, E. W., R. W. Howarth, J. N. Galloway, F. J. Dentener, P. A. Green, and C. J. Vörösmarty (2006), Riverine nitrogen export from the continents to the coasts, Global Biogeochem. Cycles, 20, GB1S91, doi:10.1029/2005GB002537.

British Survey of Fertiliser Practice (2007), Fertiliser use on farm crops for crop year 2006, report, Her Majesty's Stationery Off., London.

Choudrie, S. L., J. Jackson, J. D. Watterson, T. Murrells, N. Passant, A. Thomson, L. Cardenas, A. Leech, D. C. Mobbs, and G. Thistlethwaite (2008), UK greenhouse gas inventory, 1990-2006, report, AEA Technol., Harwell, U. K.

Clark, J. M., P. J. Chapman, J. K. Adamson, and S. J. Lane (2005), Influence of drought-induced acidification on the mobility of dissolved organic carbon in peat soils, Global Change Biol., 11, 791-809, doi:10.1111/j.1365-2486.2005.00937.x.

Cleveland, C. C., et al. (1999), Global patterns of terrestrial biological nitrogen fixation in natural systems, Global Biogeochem. Cycles, 13, 623-645, doi:10.1029/1999GB900014.

Davies, H., and C. Neal (2007), Estimating nutrient concentrations from catchment characteristics across the UK, Hydrol. Earth Syst. Sci., 11, $550-558$.

De Vries, A., and H. C. Klavers (1994), Riverine fluxes of pollutants: Monitoring strategies first, calculation methods second, Eur. Water Pollut. Contrib., 4, 12-17.

Dore, C., et al. (2007), UK emissions of air pollutants 1970 to 2005, report, AEA Technol., Harwell, U. K.

Duan, N. (1983), Smearing estimate: A non-parametric retransformation method, J. Am. Stat. Assoc., 78, 605-610, doi:10.2307/2288126.

European Commission (1991), Directive concerning urban wastewater treatment, Council Directive 91/271, Off. J. Eur. Union, 135, 40-52.

Fowler, D., R. L. Smith, J. B. A. Muller, G. Hayman, and K. J. Vincent (2005), Changes in the atmospheric deposition of acidifying compounds in the UK between 1986 and 2001, Environ. Pollut., 137, 15-25, doi:10.1016/j.envpol.2004.12.028.

Freeman, C., N. Ostle, and H. Kang (2001), An enzymic 'latch' on a global carbon store - a shortage of oxygen locks up carbon in peatlands by restraining a single enzyme, Nature, 409, 149, doi:10.1038/35051650.

Galloway, J. N., et al. (2004), Nitrogen cycles: Past, present and future, Biogeochemistry, 70, 153-226, doi:10.1007/s 10533-004-0370-0.

Harrison, J. A., N. Caraco, and S. P. Seitzinger (2005), Global patterns and sources of dissolved organic matter export to the coastal zone: Results from a spatially explicit, global model, Global Biogeochem. Cycles, 19, GB4S04, doi:10.1029/2005GB002480.

Haynes, R. J., and R. S. Swift (1989), Effect of air dried soils on pH and accumulation of mineral N, J. Soil Sci., 40, 341-347, doi:10.1111/ j.1365-2389.1989.tb01278.x.

Herridge, D. F., M. H. Peoples, and R. M. Boddy (2008), Global inputs of biological nitrogen fixation in agricultural systems, Plant Soil, 311, $1-$ 18, doi:10.1007/s11104-008-9668-3.

Hillier, S. (2001), Particulate composition and origin of suspended sediment in the R. Don, Aberdeenshire, UK, Sci. Total Environ., 265, 281-293, doi:10.1016/S0048-9697(00)00664-1.

Hope, D., M. F. Billett, R. Milne, and T. A. W. Brown (1997), Exports of organic carbon in British rivers, Hydrol. Processes, 11, 325-344, doi:10.1002/(SICI)1099-1085(19970315)11:3<325::AID-HYP476>3.0 $\mathrm{CO} ; 2-\mathrm{I}$

Kroeze, C., et al. (2003), Uncertainties in the fate of nitrogen I: An overview of sources of uncertainty illustrated with a Dutch case study, Nutrient Cycling Agroecosyst., 66, 43-69, doi:10.1023/ A: 1023339106213

Lawrence, H., K. Vincent, M. Smith, and C. Colbeck (2007), UK acid deposition monitoring network: Data summary 2006, report, AEA, Harwell, U. K.

Littlewood, I. G. (1995), Hydrological regimes, sampling strategies, and assessment of errors in mass load estimates for United Kingdom rivers, Environ. Int., 21(2), 211-220, doi:10.1016/0160-4120(95)00011-9.

Littlewood, I. G., and T. J. Marsh (2005), Annual freshwater river mass loads from Great Britain, 1975-1994: Estimation algorithm, database and monitoring network issues, J. Hydrol. Amsterdam, 304, 221-237, doi:10.1016/j.jhydrol.2004.07.031.

Littlewood, I. G., C. D. Watts, and J. M. Custance (1998), Systematic application of United Kingdom river flow and quality databases for estimating annual river mass loads (1975-1994), Sci. Total Environ., $210(1-6), 21-40$.

Marsh, T. J. (1980), Towards a nitrate balance for England and Wales, Water Serv. 84, pp. 601-606, Minist. of Agric., Fish. and Food, London.

Meybeck, M., and A. Ragu (1995), River discharges to oceans: An assessment of suspended solids, major ions, nutrients, report, 245 pp., UN Environ. Program, Nairobi.

Monteith, D. T., et al. (2007), Dissolved organic carbon trends resulting from changes in atmospheric deposition chemistry, Nature, 450, 537541, doi: $10.1038 /$ nature06316.

Naden, P. S., and A. T. McDonald (1989), Statistical modelling of water colour in the uplands: The upper Nidd catchment 1979-1987, Environ. Pollut., 60, 141-163, doi:10.1016/0269-7491(89)90224-8.

Neal, C. (2003), Dissolved and acid available particulate beryllium in eastern UK surface waters, Sci. Total Environ., 314-316, 185-208, doi:10.1016/S0048-9697(03)00103-7.

Nedwell, D. B., L. F. Dong, A. Sage, and D. J. C. Underwood (2002), Variations in the nutrient loads to the mainland UK estuaries: Correlation 
with catchment areas, urbanisation and coastal eutrophication, Estuarine Coastal Shelf Sci., 54, 951-970, doi:10.1006/ecss.2001.0867.

OSPAR Commission (2007), Data report on the comprehensive study of riverine inputs and direct discharges (RID) in 2006, Paris.

Parris, K. (1998), Agricultural nutrient balance as agri-environmental indicators: An OECD perspective, Environ. Pollut., 102, 219-225, doi:10.1016/S0269-7491(98)80036-5.

Patrick, W. H., and I. C. Mahapatra (1968), Transformations and availability to rice of nitrogen and phosphorus in waterlogged soils, Adv. Agron., 20, 323-359, doi:10.1016/S0065-2113(08)60860-3.

Powlson, D. S., and D. S. Jenkinson (1976), The effects of biocidal treatments on metabolism in soil. II. Gamma radiation, autoclaving, air drying and fumigation with chloroform or methyl bromide, Soil Biol. Biochem. 8, 179-188, doi:10.1016/0038-0717(76)90002-X.

Raymond, P. A., N.-H. Oh, R. E. Turner, and W. Broussard (2008), Anthropogenically enhanced fluxes of water and carbon from the Mississippi River, Nature, 451, 449-452, doi:10.1038/nature06505.

Rodda, J. C., and G. N. Jones (1983), Preliminary estimates of loads carried by rivers to estuaries and coastal waters around Great Britain derived from the harmonized monitoring scheme, J. Inst. Water Eng. Sci., 37, $529-539$

Rossi, A. M., M. Villarreal, M. D. Juarez, and N. C. Samman (2004), Nitrogen contents in food: A comparison between the Kjeldahl and Hach methods, J. Argent. Chem. Soc., 92, 99-108.

Seitzinger, S. P., R. V. Styles, E. W. Boyer, R. B. Alexander, G. Billen, R. W. Howarth, B. Mayer, and N. Van Breemen (2002), Nitrogen retention in rivers: Model development and application in watersheds in northeastern USA, Biogeochemistry, 57-58, 199-237, doi:10.1023/ A:1015745629794.

Seitzinger, S. P., J. A. Harrison, E. Dumont, A. H. W. Beusen, and A. F. Bouwman (2005), Sources and delivery of carbon, nitrogen, and phosphorus to the coastal zone: An overview of Global Nutrient Export from Watersheds (NEWS) models and their application, Global Biogeochem. Cycles, 19, GB4S01, doi:10.1029/2005GB002606.

Simpson, E. A. (1980), The harmonization of the monitoring of the quality of rivers in the United Kingdom, Hydrol. Sci. Bull., 25, 13-23.

Smil, V. (1999), Nitrogen in crop production: An account of global flows, Global Biogeochem. Cycles, 13(2), 647-662, doi:10.1029/ 1999GB900015.

Turner, R. F., and N. N. Rabalais (1994), Coastal eutrophication near the Mississippi River delta, Nature, 368, 619-621, doi:10.1038/368619a0.

Van Breemen, N., et al. (2002), Where did all the nitrogen go? Fate of nitrogen inputs to large watersheds in the northeastern USA, Biogeochemistry, 57-58, 267-293, doi:10.1023/A:1015775225913.

Verhoff, F. H., S. M. Yaksich, and D. A. Melfi (1980), River nutrient and chemical transport estimates, J. Environ. Eng. Div. Am. Soc. Civ. Eng., $10,591-608$.
Vitousek, P. M., J. D. Aber, R. W. Howarth, G. F. Likens, P. A. Matson, D. W. Schindler, W. H. Schlesinger, and D. G. Tilman (1997), Human alteration of the global nitrogen cycle: Sources and consequences, Ecol. Appl., 7, 737-750.

Walling, D. E., and B. W. Webb (1982), Sediment availability and the prediction of storm period sediment yields, Hydrol. Sci. J., 27, 246.

Walling, D. E., and B. W. Webb (1985), Estimating the discharge of contaminants to coastal waters by rivers: Some cautionary comments, Mar. Pollut. Bull., 16, 488-492, doi:10.1016/0025-326X(85)90382-0.

Webb, B. W., J. M. Phillips, D. E. Walling, I. G. Littlewood, C. D. Watts, and G. J. L. Leeks (1997), Load estimation methodologies for British rivers and their relevance to the LOIS RACS (R) programme, Sci. Total Environ., 194-195, 379-389, doi:10.1016/S0048-9697(96)05377-6.

Webb, B. W., J. M. Phillips, and D. E. Walling (2000), A new approach to deriving "best-estimate" chemical fluxes for rivers draining the LOIS study area, Sci. Total Environ., 251-252, 45-54, doi:10.1016/S00489697(00)00413-7.

Whitmore, A. P., N. J. Bradbury, and P. A. Johnson (1992), Potential contribution of ploughed grassland to nitrate leaching, Agric. Ecosyst. Environ., 39, 221-233, doi:10.1016/0167-8809(92)90056-H.

Worrall, F., and T. P. Burt (2001), Inter-annual controls on nitrate export from an agricultural catchment-how much land-use change is safe?, J. Hydrol. Amsterdam, 243, 228-241, doi:10.1016/S00221694(00)00411-X

Worrall, F., and T. P. Burt (2007), Flux of dissolved organic carbon from U.K. rivers, Global Biogeochem. Cycles, 21(1), GB1013, doi:10.1029/ 2006GB002709.

Worrall, F., T. Guillbert, and T. Besien (2007a), The flux of carbon from rivers: The case for flux from England and Wales, Biogeochemistry, 86, 63-75, doi:10.1007/s10533-007-9145-8.

Worrall, F., T. P. Burt, J. K. Adamson, M. Reed, J. Warburton, A. Armstrong, and M. G. Evans (2007b), Predicting the future carbon budget of an upland peat catchment, Clim. Change, 85, 139-158, doi:10.1007/s10584-007-9300-1.

T. P. Burt, Department of Geography, Science Laboratories, Durham University, South Road, Durham DH1 3LE, UK.

N. J. K. Howden and M. J. Whelan, Natural Resources Department, School of Applied Sciences, Cranfield University, Cranfield MK43 0AL, UK.

F. Worrall, Department of Geological Sciences, Science Laboratories, Durham University, South Road, Durham, DH1 3LE, UK. (fred.worrall@ durham.ac.uk) 